\title{
Assessment of Trace Metals in Camelus dromedarius Meat from Mauritania
}

\author{
El Boukhary Ahmed ${ }^{1} \cdot$ Mohamed Salem El Mahmoud Hamed $^{2} \cdot$ Babah Sidi Moktar $^{3} \cdot$ Angelo Santana-Del Pino $^{4} \cdot$ \\ Mohamed Brahim ${ }^{2} \cdot$ Mariem Youssouf Issa $^{5} \cdot$ Mohamed Lemine Zamel $^{2} \cdot$ Sarah Montesdeoca-Esponda ${ }^{6}$ (I)
}

Received: 8 November 2021 / Accepted: 1 February 2022 / Published online: 10 February 2022

(c) The Author(s) 2022

\begin{abstract}
In Mauritania, the dromedary breeding is the most widespread pastoral activity, and it is considered as the first source of animal protein; however, the research on meat is relatively rare compared with fish, especially in relation with the presence of trace metals. In this work, livers, kidneys, and muscles of 25 Camelus dromedarius were collected from butcheries in Nouakchott (Mauritania) between February and April 2020 to study the concentration of trace metals (three essential metals: cooper $(\mathrm{Cu})$, iron $(\mathrm{Fe})$, and zinc $(\mathrm{Zn})$, and four toxic metals: mercury $(\mathrm{Hg})$, arsenic $(\mathrm{As})$, cadmium $(\mathrm{Cd})$, and lead $(\mathrm{Pb}))$. Statistical treatment did not show significant differences associated with age $(P=0.7004)$, sex $(P=0.9353)$, or type of diet (0.9951) in the found concentration of the target substances, but the differences were significant between metals and between organs $(P<0.0001)$. The mean concentrations of the essential metals were $0.80 \mathrm{mg} / 100 \mathrm{~g}$ for Cu, $6.02 \mathrm{mg} / 100 \mathrm{~g}$ for $\mathrm{Fe}$, and $3.28 \mathrm{mg} / 100 \mathrm{~g}$ for $\mathrm{Zn}$, and the ratios between these concentrations were significant $(P<0.0001$ in all cases $)$, with $[\mathrm{Fe}]>[\mathrm{Zn}]>[\mathrm{Cu}]$. Cu was most concentrated in the liver, Fe in the kidney, and $\mathrm{Zn}$ in muscle. The mean concentrations of toxic metals were $0.055 \mathrm{mg} / \mathrm{kg}$ for As, $0.064 \mathrm{mg} / \mathrm{kg}$ for Cd, $0.040 \mathrm{mg} / \mathrm{kg}$ for Pb, and $0.027 \mathrm{mg} / \mathrm{kg}$ for $\mathrm{Hg}$. They also exhibited significant difference between organs. $\mathrm{Hg}$ and $\mathrm{Pb}$ showed their largest concentrations in the liver, whereas $\mathrm{As}$ and $\mathrm{Cd}$ reached their maximum values in the kidney. Therefore, the found concentrations in all cases were lower than the admissible level of trace metals.
\end{abstract}

Keywords Trace metals $\cdot$ Camel meat $\cdot$ Dromedary meat $\cdot$ Mauritania $\cdot$ Camelus dromedaries

Sarah Montesdeoca-Esponda sarah.montesdeoca@ulpgc.es

1 Ministère de Santé Mauritania, Nouakchott, Mauritania

2 Département Chimie Microbiologie Et Suivi du Milieu Aquatique (DCM-SMA), Office National d'inspection Sanitaire Des Produits de La Pêche Et de L'Aquaculture (ONISPA), 1416 Nouadhibou, Mauritania

3 Département Biologie, Faculté Des Sciences Et Techniques (FST), Université de Nouakchott Al-Aasriya, Campus Universitaire de Nouakchott, 880, Route de Nouadhibou, Nouakchott, Mauritania

4 Departamento de Matemáticas, Universidad de Las Palmas de Gran Canaria, Campus Universitario de Tafira, s/n, 35017 Las Palmas de Gran Canaria, Spain

5 Institut Supérieur de Biotechnologie de Sfax, Université de Sfax-Tunisie, Sfax, Tunisia

6 Instituto de Estudios Ambientales Y Recursos Naturales (I-UNAT), Universidad de Las Palmas de Gran Canaria, 35017 Las Palmas de Gran Canaria, Spain

\section{Introduction}

Dromedary and camel meat are rich in essentials amino acids, and it is considered as the first source of animal protein [1]. This meat, with its good carcass yield and the dietary quality of its meat, is appreciated and consumed on a large scale in Mauritania as well as in West Africa and Middle East countries [2-4].

Mauritania is classified among the countries where the number of dromedaries is growing rapidly [1] and their meat consumption has increased recently. Thus, the dromedary breeding is the most widespread pastoral activity in the country, with a number of herds which are estimated as the most important of the countries of North, West, and Central Africa and as the third at the global level [2,3].

However, dromedaries, like other animals, are exposed to many sources of pollution, which are enormous, and anthropogenic contaminants may accumulate in its meat. For example, some trace metals are known as toxic substances 
and they can cause serious disorders [5] in the short or long term [6], so, evaluation of its levels in animal's organs allows us to inquire into the chemical quality of the food and the environment. When these elements exist in animal feed, they are accumulated in the kidneys and livers [7, 8]; therefore, these organs represent a significant source of exogenous dietary intake of trace elements when they are consumed by humans [9].

The presence of different metals has been studied in camels and dromedaries, and concentrations up to hundreds of $\mathrm{mg} / \mathrm{kg}$ were found in several matrices, such as meat [6, 10-14], organs [4, 12, 15-17], blood [18-21], or milk [22] as shown in Table 1.

Most of these studies have been carried out in countries where camel is an important food source for the population (Iran, Saudi Arabia, Algeria, Nigeria, Morocco, Sudan, Iraq), so the presence of certain trace metals could affect the quality of their nutritional properties to humans. Hence, it is important to know the content of these elements at the same time that the food nutritional studies are conducted.

However, in Mauritania, the research on meat is relatively scarce compared with fish, especially regarding the presence of toxic metals and health risk related. For the best of our knowledge, no studies have been performed in Mauritania to estimate the concentration levels of metals present in camel or dromedary meat.

Mauritania is known by the iron exploitation. Its production of this metal in 2020 was 12.5 billion tons [25]. Recently, the country has begun the exploitation of other metals such as copper and gold in the region of Inchiri, where the dromedaries in Mauritania go looking for pasture. These exploitations may have an impact on environment especially plant which is eaten by animals.

Thus, the main object of this work was to study some trace metals levels in dromedary meat from butcheries of Nouakchott city. The target essential metals were cooper $(\mathrm{Cu})$, iron $(\mathrm{Fe})$, and zinc $(\mathrm{Zn})$, while the selected target toxic metals were mercury $(\mathrm{Hg})$, arsenic $(\mathrm{As})$, cadmium $(\mathrm{Cd})$, and lead $(\mathrm{Pb})$. A statistical analysis was conducted to know if the differences found between the metal concentrations were significantly related with the studied organs, and with the age, type of diet, or sex of the animals. The measured concentration levels of target analytes were also compared with studies analyzing camel and dromedary meat from other regions.

\section{Experimental}

\section{Sampling}

Dromedary meat was collected randomly from some butcheries located in Nouakchott city (Mauritania) between
February and April 2020. Just after sampling, the samples were transported to the laboratory under ice. A total of 25 animals were dissected to separate their livers, kidneys, and muscles. These animals were classified as the following: 9 young ( $<3$ years old), 7 adults ( $4-5$ years old), and 9 old (10 years old). In each age's class, three animals were fed on natural food and the others were fed on forage (crops that have been cut and dried to be used to feed animals). The origin of animals could not be identified for some of them; however, the majority came from Inchiri region which is close to Nouakchott.

\section{Sample Preparation and Analyses}

At laboratory, individual samples $(20 \pm 3 \mathrm{~g}$ of liver and kidney and $45 \pm 5 \mathrm{~g}$ of muscle) were separately dried to constant weight at $-46^{\circ} \mathrm{C}$ for $48 \mathrm{~h}$ with a lyophilizer system in acidwashed flask. Moisture content was calculated and samples were ground to a fine powder using a porcelain mortar and a pestle.

Samples of 0.2-g dry weight (dw) were digested by duplicate according to El Mahmoud et al. [26]. and Taweel et al. [27]. Briefly, samples were placed in microwave-closed vessels with a mixture of ultra-pure nitric acid $67 \%$ and hydrogen peroxide 30\% (3:1) [28] at room temperature for $1 \mathrm{~h}$. Digestion conditions applied in the microwave system were as follows: $3 \mathrm{~min}$ at $250 \mathrm{~W} ; 5 \mathrm{~min}$ at $650 \mathrm{~W} ; 22 \mathrm{~min}$ at $500 \mathrm{~W}$; and finally $5 \mathrm{~min}$ at $0 \mathrm{~W}$ and vent. Hydrogen peroxide with nitric acid was added to the samples because peroxide decreases nitrous vapors and speeds up the digestion of organic substances by elevating the reaction temperature [29]. Then the digested samples were diluted to $20 \mathrm{~mL}$ with deionized water (milli-Q quality).

The trace metal analysis, except for $\mathrm{Hg}$, was conducted using Indicative Plasma Couple-optic emission specter (ICP-OES), which limit of detection (LOD) is $0.001 \mathrm{mg} /$ $\mathrm{kg}$. $\mathrm{Hg}$ was analyzed using Direct Mercury Analyzer ( $\mathrm{LOD}=0.003 \mathrm{mg} / \mathrm{kg}$ ) according to the method "MA.207-Hg 2.0. Rév. 4. Centre d'expertise en analyse environnementale du Québec CEAEQ" [30]. Standard solution and $r$-square of the calibration curves are shown in Table 2.

\section{Statistical Analyses}

Concentrations of each metal were initially described as mean \pm standard deviation (sd) for every organ, age group, and type of diet (natural or forage). As data were collected several times for the same individual (in liver, kidney, and muscle), linear mixed effects models have been used to evaluate the significance of the differences between the concentrations of the various metals as well as the differences in metal concentrations between organs, adjusting for the effects of age, type of diet, and sex, and taking into account 
Table 1 Metal concentrations found in different matrices from camel

\begin{tabular}{|c|c|c|c|c|}
\hline Sample & Metals & Location & Concentration range $(\mathrm{mg} / \mathrm{kg})$ & Ref \\
\hline Liver, kidney, muscle & $\mathrm{Cu}, \mathrm{Zn}, \mathrm{Fe}, \mathrm{Hg}, \mathrm{As}, \mathrm{Cd}, \mathrm{Pb}$ & Mauritania & $\begin{array}{l}\mathrm{Cu}: 1.80-68.2 \\
\mathrm{Zn}: 9.7-77.9 \\
\text { Fe: } 19.8-167.2 \\
\mathrm{Hg}: 0.049-0.0935 \\
\text { As: }<0.0001-0.4606 \\
\mathrm{Cd}:<0.0001-1.0483 \\
\mathrm{~Pb}: 0.0164-0.5408\end{array}$ & This work \\
\hline Liver, kidney, muscle & $\mathrm{Pb}, \mathrm{Cd}, \mathrm{As}, \mathrm{Cu}, \mathrm{Zn}, \mathrm{Fe}$ & Saudi Arabia & $\begin{array}{l}\text { Pb: } 0.00011-0.00395 \\
\text { Cd: } 0.00112-0.01523 \\
\text { As: } 0.0074-0.09995 \\
\text { Cu: } 0.00006-0.00502 \\
\text { Zn: } 0.22-6.77 \\
\text { Fe: } 2.14-20.98\end{array}$ & {$[4]$} \\
\hline Sausages & $\mathrm{Cr}, \mathrm{Cu}, \mathrm{Mn}, \mathrm{Zn}, \mathrm{Ni}, \mathrm{Fe}$ & Sudan & $\begin{array}{l}\text { Cr: } 0.36 \\
\mathrm{Cu}: 0.02 \\
\mathrm{Mn}: 0.04 \\
\mathrm{Zn}: 0.16 \\
\mathrm{Ni}: 0.01 \\
\text { Fe: } 37.81\end{array}$ & {$[6]$} \\
\hline Meat & $\mathrm{Fe}, \mathrm{Mn}, \mathrm{Cu}, \mathrm{Zn}, \mathrm{Pb}, \mathrm{Cd}$, and $\mathrm{Hg}$ & Saudi Arabia & $\begin{array}{l}\text { Fe: } 70.98-113.07 \\
\text { Mn: } 0.82-2.80 \\
\mathrm{Cu}: 1.33-3.20 \\
\mathrm{Zn}: 16.74-40.17 \\
\mathrm{~Pb}: 2.01-5.48 \\
\mathrm{Cd}: 0.83-1.07 \\
\mathrm{Hg}: 0.024-0.054\end{array}$ & {$[10]$} \\
\hline Meat & $\mathrm{Fe}, \mathrm{Cu}, \mathrm{Zn}, \mathrm{Pb}, \mathrm{Cd}, \mathrm{Hg}$ & Algeria & $\begin{array}{l}\text { Fe: } 70.98-75.03 \\
\mathrm{Cu}: 2.20-2.82 \\
\mathrm{Zn}: 23.51-40.17 \\
\mathrm{~Pb}: 2.01-3.21 \\
\mathrm{Cd}: 0.83-0.91 \\
\mathrm{Hg}: 0.024-0.032\end{array}$ & [11] \\
\hline Kidney, liver, muscle, hide, blood & $\mathrm{Pb}, \mathrm{Cd}, \mathrm{Cr}$ & Nigeria & $\begin{array}{l}\text { Pb: } 0.11-1.17 \\
\text { Cd: } 0.01-0.8 \\
\text { Cr: } 0.13-0.59\end{array}$ & [12] \\
\hline Meat, liver, lung, heart, kidney & $\mathrm{Co}, \mathrm{Zn}, \mathrm{Cd}, \mathrm{Pb}$ & Morocco & $\begin{array}{l}\text { Co: } 1.10-14.22 \\
\mathrm{Zn}: 4.05-10.88 \\
\mathrm{Cd}: 0.023-0.69 \\
\mathrm{~Pb}: 0.71-1.33\end{array}$ & {$[13]$} \\
\hline Meat & $\mathrm{Zn}, \mathrm{Fe}, \mathrm{Cu}$ & Algeria & $\begin{array}{l}\text { Zn: } 140.56 \\
\text { Fe: } 61 \\
\text { Cu: } 13.22\end{array}$ & [14] \\
\hline Liver, kidney, muscle & $\mathrm{Cd}, \mathrm{Zn}, \mathrm{Cu}, \mathrm{Co}$ & Iraq & $\begin{array}{l}\text { Cd: } 2.961-4.191 \\
\text { Zn: } 28.347-138.221 \\
\text { Cu: } 4.663-26.754 \\
\text { Co: } 1.913-8.194\end{array}$ & [15] \\
\hline Liver, muscle & $\mathrm{As}, \mathrm{Cd}, \mathrm{Cr}, \mathrm{Pb}, \mathrm{Cu}, \mathrm{Fe}, \mathrm{Mn}, \mathrm{Zn}, \mathrm{Co}$ & Iran & $\begin{array}{l}\text { As: } 0.100-1.292 \\
\text { Cd: } 0.012-0.029 \\
\text { Cr: } 2.333-9.930 \\
\text { Pb: } 0.093-1.563 \\
\text { Cu: } 1.220-4.381 \\
\text { Fe: } 38.088-101.927 \\
\text { Mn: } 0.301-1.293 \\
\text { Zn: } 23.254-171.463 \\
\text { Co: } 0.006-0.995\end{array}$ & [16] \\
\hline
\end{tabular}


Table 1 (continued)

\begin{tabular}{|c|c|c|c|c|}
\hline Sample & Metals & Location & Concentration range $(\mathrm{mg} / \mathrm{kg})$ & Ref \\
\hline Liver, kidney, muscle & $\mathrm{Pb}, \mathrm{Cd}, \mathrm{Hg}, \mathrm{Cu}, \mathrm{Zn}$ & Egypt & $\begin{array}{l}\text { Pb: } 0.17-0.49 \\
\text { Cd: } 0.03-0.12 \\
\text { Hg: } 0.39-1.19 \\
\text { Cu: } 0.10-8.82 \\
\text { Zn: } 3.25-8.35\end{array}$ & [17] \\
\hline Blood serum & $\mathrm{Fe}, \mathrm{Zn}, \mathrm{Cu}, \mathrm{Cd}, \mathrm{Mo}, \mathrm{Se}, \mathrm{Mn}, \mathrm{Pb}$ & USA & $\begin{array}{l}\text { Fe: } 2448.2^{*} \\
\text { Zn: } 274^{*} \\
\text { Cu: } 198.7^{*} \\
\text { Cd: } 89.8^{*} \\
\text { Mo: } 12.3^{*} \\
\text { Se: } 10.5^{*} \\
\text { Mn: } 0.74^{*} \\
\text { Pb: } 0.17^{*}\end{array}$ & [18] \\
\hline Seminal plasma & $\mathrm{Cd}$ & USA & $50-240 *$ & [19] \\
\hline Blood & $\mathrm{Cu}, \mathrm{Se}$ & Saudi Arabia & $\begin{array}{l}\mathrm{Cu}: 58.6-70.3 \\
\text { Se: } 4.6-5.3\end{array}$ & [20] \\
\hline Blood & $\mathrm{Zn}, \mathrm{Cu}$ & Sudan & $\begin{array}{l}\mathrm{Zn}: 597-813 \\
\mathrm{Cu}: 51.0-67.1\end{array}$ & [21] \\
\hline Milk & $\mathrm{Cd}, \mathrm{Pb}, \mathrm{Hg}$ & Iran & $\begin{array}{l}\mathrm{Cd}: 0.000006-0.00425 \\
\mathrm{~Pb}: 0.00012-0.01674 \\
\mathrm{Hg}: 0.00103-0.00561\end{array}$ & [22] \\
\hline Neck, shoulder, plate, leg and loin & $\mathrm{Mg}, \mathrm{Pb}, \mathrm{Fe}, \mathrm{Hg}$ & Iraq & $\begin{array}{l}\mathrm{Mg}: 7.50-26.2 \\
\text { Pb: } 1.3-5.5 \\
\text { Fe: } 35.0-350.0 \\
\text { Hg: } 0.0011-0.0045\end{array}$ & [23] \\
\hline Liver, muscle & $\mathrm{Pb}, \mathrm{Cd}, \mathrm{As}$ & Saudi Arabia & $\begin{array}{l}\mathrm{Pb}: 0.0073-0.0105 \\
\mathrm{Cd}: 0.0009-0.0013 \\
\text { As: } 0.008-0.0116\end{array}$ & [24] \\
\hline
\end{tabular}

Table 2 Standard concentrations and $r$-square of the calibration curves

\begin{tabular}{llllllll}
\hline $\begin{array}{l}\text { Standards } \\
\text { Metals }\end{array}$ & 1 & 2 & 3 & 4 & 5 & 6 & $r$-square \\
\hline $\mathrm{Cu}(\mathrm{mg} / \mathrm{l})$ & 0.1 & 0.5 & 1 & 2 & 5 & 10 & 0.9960 \\
$\mathrm{Zn} \mathrm{(mg/l)}$ & 0.1 & 0.5 & 1 & 2 & 5 & 10 & 0.9990 \\
$\mathrm{Fe} \mathrm{(mg/l)}$ & 0.1 & 0.5 & 1 & 2 & 5 & 10 & 0.9961 \\
$\mathrm{As} \mathrm{(mg/l)}$ & 0.1 & 0.5 & 1 & 2 & 5 & 10 & 0.9994 \\
$\mathrm{Cd}(\mathrm{mg} / \mathrm{l})$ & 0.1 & 0.5 & 1 & 2 & 5 & 10 & 0.9967 \\
$\mathrm{~Pb}(\mathrm{mg} / \mathrm{l})$ & 0.1 & 0.5 & 1 & 2 & 5 & 10 & 0.9976 \\
$\mathrm{Hg}(\mathrm{ng})$ & 10 & 20 & 50 & 100 & 150 & 200 & 0.9998 \\
\hline
\end{tabular}

the random effect of the individual. When significant differences were detected, Tukey post hoc tests were performed to identify between which specific organs differences occurred and to evaluate their magnitude. Metal concentrations were logarithmically transformed to meet the normality hypothesis. Normality was tested using the Shapiro-Wilk test. Due to this logarithmic transformation, the magnitude of the differences in metal concentration between different organs was expressed in proportional terms (ratios of concentrations), accompanied by their corresponding $95 \%$ confidence intervals. A significance level of 5\% was used for all contrasts. General statistical analysis and figures were performed using
R software version 4.0.1 [31]. Mixed model fitting was performed using also in $\mathrm{R}$ the nlme package [32], and adjusted means were evaluated using the emmeans package [33].

\section{Results}

Means and SD of metal concentrations found in meat samples, separated according to age group and type of diet, are reported for essential metals $(\mathrm{Cu}, \mathrm{Zn}$, and $\mathrm{Fe})$ and for toxic metals $(\mathrm{Hg}, \mathrm{Cd}, \mathrm{As}$, and $\mathrm{Pb})$ in Table 3. 
Table 3 Metal concentrations in dromedary meat and SD

\begin{tabular}{|c|c|c|c|c|c|c|c|c|c|}
\hline \multirow[t]{2}{*}{ Age } & \multirow[t]{2}{*}{ Organ } & \multirow[t]{2}{*}{ Food } & \multicolumn{3}{|c|}{ Essentials metals (mg/100 g) } & \multicolumn{4}{|c|}{ Toxics metals (mg/kg) } \\
\hline & & & $\mathrm{Cu}$ & $\mathrm{Zn}$ & $\mathrm{Fe}$ & $\mathrm{Hg}$ & As & $\mathrm{Cd}$ & $\mathrm{Pb}$ \\
\hline \multirow[t]{6}{*}{$0-3$ years } & \multirow[t]{2}{*}{ Liver } & Natural food & $6.82 \pm 2.45$ & $4.26 \pm 0.90$ & $5.77 \pm 2.47$ & $0.0320 \pm 0.0200$ & $0.1094 \pm 0.0899$ & $0.1086 \pm 0.0818$ & $0.1420 \pm 0.2460$ \\
\hline & & Animal feed & $2.91 \pm 3.16$ & $2.73 \pm 1.73$ & $6.93 \pm 4.30$ & $0.0878 \pm 0.0495$ & $0.1684 \pm 0.1779$ & $0.2300 \pm 0.2218$ & $0.1407 \pm 0.1514$ \\
\hline & \multirow[t]{2}{*}{ Muscle } & Natural food & $0.35 \pm 0.38$ & $7.79 \pm 2.50$ & $1.98 \pm 1.07$ & $0.0049 \pm 0.0008$ & $0.0145 \pm 0.0157$ & $0.0069 \pm 0.0120$ & $0.0164 \pm 0.0283$ \\
\hline & & Animal feed & $0.69 \pm 0.89$ & $5.62 \pm 2.19$ & $3.00 \pm 0.95$ & $0.0388 \pm 0.0389$ & $0.0059 \pm 0.0145$ & $0.0670 \pm 0.1050$ & $0.1693 \pm 0.1994$ \\
\hline & \multirow[t]{2}{*}{ Kidney } & Natural food & $0.29 \pm 0.13$ & $1.85 \pm 0.49$ & $10.55 \pm 3.34$ & $0.0179 \pm 0.0035$ & $0.3634 \pm 0.1281$ & $0.4103 \pm 0.1466$ & $0.0242 \pm 0.0420$ \\
\hline & & Animal feed & $1.03 \pm 1.44$ & $2.10 \pm 1.46$ & $10.51 \pm 3.29$ & $0.0486 \pm 0.0251$ & $0.1001 \pm 0.0819$ & $0.1491 \pm 0.1295$ & $0.2232 \pm 0.4459$ \\
\hline \multirow[t]{6}{*}{$4-5$ years } & \multirow[t]{2}{*}{ Liver } & Natural food & $5.75 \pm 2.41$ & $2.99 \pm 0.86$ & $8.26 \pm 0.72$ & $0.0266 \pm 0.0074$ & $0.2912 \pm 0.4232$ & $0.0313 \pm 0.0302$ & $0.1614 \pm 0.2652$ \\
\hline & & Animal feed & $3.61 \pm 2.98$ & $2.84 \pm 0.73$ & $10.23 \pm 3.76$ & $0.0935 \pm 0.0338$ & $0.4606 \pm 0.3395$ & $0.3564 \pm 0.3304$ & $0.1060 \pm 0.2120$ \\
\hline & \multirow[t]{2}{*}{ Muscle } & Natural food & $0.55 \pm 0.43$ & $7.32 \pm 3.38$ & $2.17 \pm 1.55$ & $0.0093 \pm 0.0100$ & $<0.0001$ & $<0.0001$ & $0.0461 \pm 0.0799$ \\
\hline & & Animal feed & $1.58 \pm 2.30$ & $4.72 \pm 2.32$ & $4.29 \pm 1.69$ & $0.0555 \pm 0.0274$ & $<0.0001$ & $0.1858 \pm 0.1839$ & $0.0349 \pm 0.0699$ \\
\hline & \multirow[t]{2}{*}{ Kidney } & Natural food & $0.39 \pm 0.18$ & $1.73 \pm 0.39$ & $12.74 \pm 0.04$ & $0.0251 \pm 0.0109$ & $0.3922 \pm 0.3716$ & $0.1522 \pm 0.1866$ & $0.0977 \pm 0.0847$ \\
\hline & & Animal feed & $0.57 \pm 0.20$ & $2.73 \pm 2.68$ & $12.70 \pm 6.20$ & $0.0538 \pm 0.0257$ & $0.3142 \pm 0.4498$ & $1.0483 \pm 1.2258$ & $0.2244 \pm 0.3374$ \\
\hline \multirow[t]{6}{*}{10 years } & \multirow[t]{2}{*}{ Liver } & Natural food & $3.49 \pm 3.94$ & $3.13 \pm 2.59$ & $5.09 \pm 3.45$ & $0.0377 \pm 0.0058$ & $0.0698 \pm 0.0259$ & $0.0524 \pm 0.0255$ & $0.1648 \pm 0.0338$ \\
\hline & & Animal feed & $4.73 \pm 3.20$ & $3.68 \pm 0.77$ & $6.34 \pm 1.45$ & $0.0528 \pm 0.0269$ & $0.1450 \pm 0.0628$ & $0.2024 \pm 0.0755$ & $0.2188 \pm 0.2016$ \\
\hline & \multirow[t]{2}{*}{ Muscle } & Natural food & $0.62 \pm 0.72$ & $6.10 \pm 3.25$ & $5.10 \pm 3.53$ & $0.0085 \pm 0.0063$ & $0.0175 \pm 0.0163$ & $0.0135 \pm 0.0234$ & $0.1691 \pm 0.1757$ \\
\hline & & Animal feed & $0.33 \pm 0.18$ & $5.99 \pm 2.64$ & $4.13 \pm 3.11$ & $0.0119 \pm 0.0111$ & $0.1181 \pm 0.1620$ & $0.0896 \pm 0.1701$ & $0.5408 \pm 1.1439$ \\
\hline & \multirow[t]{2}{*}{ Kidney } & Natural food & $0.18 \pm 0.25$ & $0.97 \pm 1.37$ & $16.72 \pm 0.01$ & $0.0268 \pm 0.0138$ & $0.3145 \pm 0.4448$ & $0.3594 \pm 0.5083$ & $0.0849 \pm 0.1200$ \\
\hline & & Animal feed & $0.82 \pm 1.00$ & $2.70 \pm 2.40$ & $9.34 \pm 5.45$ & $0.0237 \pm 0.0144$ & $0.3107 \pm 0.2360$ & $0.3010 \pm 0.2890$ & $0.0660 \pm 0.0946$ \\
\hline
\end{tabular}

Moisture content varied widely between the liver and other organs. It was $65.3 \pm 3.65 \%, 75.69 \pm 3.32 \%$, and $79.95 \pm 3.49 \%$ for the liver, muscle, and kidney, respectively. These results are similar to other found in camel meat from Algeria (Ouargla), containing $76 \pm 0.8 \%$ of moisture [14] while Hammad et al. reported values of $74.72 \pm 2.45 \%$ for camel meat from Sudan [34].

\section{Essentials Metals}

No significant differences associated with age $(P=0.7004)$, sex $(P=0.9353)$, or type of diet $(0.9951)$ were detected in the concentration of any of the analyzed metals, but the differences were significant between metals $(P<0.0001)$ and between organs $(P<0.0001)$ as well as in the interaction between both variables. When adjusted by age, type of diet, and sex, and averaging across organs, the mean concentrations of essential metals were $0.80 \mathrm{mg} / 100 \mathrm{~g} \mathrm{(CI} \mathrm{95 \%}$ $[0.68,0.94])$ for $\mathrm{Cu}, 6.02 \mathrm{mg} / 100 \mathrm{~g}(C I 95 \%$ [5.06, 7.14]) for $\mathrm{Fe}$, and $3.28 \mathrm{mg} / 100 \mathrm{~g}(C I 95 \%[2.79,3.86])$ for $\mathrm{Zn}$. Table 4 shows the ratios of the adjusted mean concentrations between these metals as well as their corresponding 95\% confidence intervals and the $P$-values for testing if these ratios are equal to one. It can be seen that all ratios between these concentrations were significant $(P<0.0001$ in all cases), with $[\mathrm{Fe}]>[\mathrm{Zn}]>[\mathrm{Cu}]$.

Nevertheless, these concentrations were not uniform through the various organs. Essentials metal $(\mathrm{Cu}, \mathrm{Zn}$, and $\mathrm{Fe}$ ) concentrations showed a variable level in the different organs. Table 5 shows the adjusted mean concentrations
Table 4 Ratios between adjusted mean concentrations of metals

\begin{tabular}{lllll}
\hline Type & Metals & Ratio & $C I 95 \%$ & $P$ \\
\hline Essential & $\mathrm{Cu} / \mathrm{Fe}$ & 0.134 & {$[0.106,0.171]$} & $<0.0001$ \\
& $\mathrm{Cu} / \mathrm{Zn}$ & 0.246 & {$[0.195,0.310]$} & $<0.0001$ \\
& $\mathrm{Fe} / \mathrm{Zn}$ & 1.832 & {$[1.447,2.318]$} & $<0.0001$ \\
Toxic & $\mathrm{Ar} / \mathrm{Cd}$ & 0.889 & {$[0.520,1.520]$} & 0.9423 \\
& $\mathrm{Ar} / \mathrm{Pb}$ & 1.302 & {$[0.762,2.224]$} & 0.5819 \\
& $\mathrm{Ar} / \mathrm{Hg}$ & 1.753 & {$[1.026,2.997]$} & 0.0360 \\
& $\mathrm{Cd} / \mathrm{Pb}$ & 1.463 & {$[0.856,2.501]$} & 0.2586 \\
& $\mathrm{Cd} / \mathrm{Hg}$ & 1.971 & {$[1.153,3.369]$} & 0.0066 \\
& $\mathrm{~Pb} / \mathrm{Hg}$ & 1.347 & {$[0.788,2.302]$} & 0.4771 \\
\hline
\end{tabular}

(with 95\% confidence intervals) of each essential metal in the various organs. These means and confidence intervals are depicted in Fig. 1, where it can be seen that, apparently, $\mathrm{Cu}$ is most concentrated in the liver, $\mathrm{Fe}$ in the kidney, and $\mathrm{Zn}$ in muscle. Table 6 shows the ratios between these concentrations.

The mean concentration of $\mathrm{Cu}$ in the liver is 8.71 times greater than in muscle and 6.98 times greater than in the kidney. Both differences are significant $(P<0.0001)$. However, the mean value of the concentration of $\mathrm{Cu}$ in muscle is only the $80 \%$ of the value in the kidney, this difference being not significant $(P=0.6770)$. So, $\mathrm{Cu}$ concentration in the organs follows the order liver $>$ muscle $=$ kidney.

With respect to $\mathrm{Zn}$, the adjusted mean concentration of this metal (Table 5) in the liver is $56 \%$ of the mean concentration in muscle and 1.75 times greater 
Table 5 Adjusted mean and $95 \%$ confidence interval for concentration of metals by organ

\begin{tabular}{lllll}
\hline Type & Metal & Liver & Muscle & Kidney \\
\hline Essential & $\mathrm{Cu}$ & $3.279[2.132,5.041]$ & $0.377[0.249,0.569]$ & $0.470[0.304,0.725]$ \\
& $\mathrm{Zn}$ & $3.243[2.690,3.908]$ & $5.826[4.875,6.962]$ & $1.848[1.529,2.233]$ \\
& $\mathrm{Fe}$ & $9.140[7.686,10.869]$ & $9.062[5.812,14.126]$ & $12.604[10.870,14.614]$ \\
Toxic & $\mathrm{Hg}$ & $0.044[0.030,0.065]$ & $0.010[0.007,0.015]$ & $0.024[0.017,0.035]$ \\
& $\mathrm{Ar}$ & $0.116[0.062,0.210]$ & $0.009[0.001,0.023]$ & $0.134[0.073,0.240]$ \\
& $\mathrm{Cd}$ & $0.091[0.044,0.178]$ & $0.015[0.004,0.036]$ & $0.126[0.063,0.243]$ \\
& $\mathrm{Pb}$ & $0.054[0.023,0.118]$ & $0.030[0.010,0.068]$ & $0.028[0.009,0.065]$ \\
\hline
\end{tabular}

Fig. 1 Adjusted mean and 95\% confidence interval for concentration of essential metals by organ
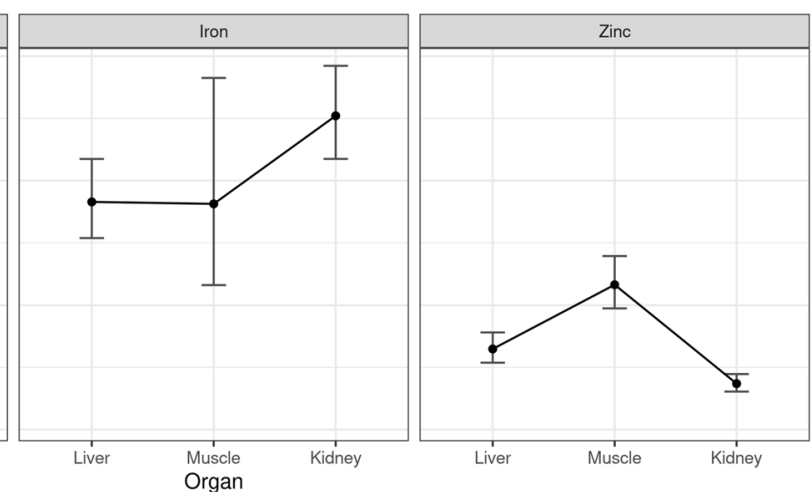

Table 6 Ratios of concentration of metals between organs. For each ratio, a 95\% confidence interval is shown, as well as a $p$-value for testing its significance

\begin{tabular}{lllll}
\hline Type & Metal & Liver/muscle & Liver/kidney & Muscle/kidney \\
\hline Essential & $\mathrm{Cu}$ & $8.71[4.62,16.41](\mathrm{P}<.0001)$ & $6.98[3.65,13.33](\mathrm{P}<.0001)$ & $0.80[0.43,1.51](\mathrm{P}=0.6770)$ \\
& $\mathrm{Zn}$ & $0.56[0.41,0.75](\mathrm{P}<.0001)$ & $1.75[1.29,2.37](\mathrm{P}=0.0002)$ & $3.14[2.34,4.22](\mathrm{P}<.0001)$ \\
& $\mathrm{Fe}$ & $1.01[0.55,1.86](P=0.9991)$ & $0.73[0.54,0.97](P=0.0345)$ & $0.72[0.40,1.30](P=0.2909)$ \\
Toxic & $\mathrm{Hg}$ & $4.23[2.68,6.66](P<0.0001)$ & $1.82[1.15,2.89](P=0.0078)$ & $0.43[0.27,0.68](P=0.0001)$ \\
& $\mathrm{Ar}$ & $6.50[2.69,15.67](P<0.0001)$ & $0.88[0.36,2.13](P=0.9316)$ & $0.13[0.06,0.32](P<0.0001)$ \\
& $\mathrm{Cd}$ & $4.05[1.51,10.87](P=0.0036)$ & $0.74[0.27,2.02](P=0.7541)$ & $0.18[0.07,0.49](P=0.0004)$ \\
& $\mathrm{Pb}$ & $1.64[0.78,3.42](P=0.2487)$ & $1.71[0.81,3.62](P=0.2041)$ & $1.05[0.50,2.20](P=0.9886)$ \\
\hline
\end{tabular}

than in the kidney. Also, the mean concentration in muscle is 3.14 times higher than the one found in the kidney, being all the differences significant $(P<0.0002)$. So, $\mathrm{Zn}$ concentration in the organs follows the order muscle $>$ liver $>$ kidney.

Regarding the analysis of $\mathrm{Fe}$, the mean concentration (Table 6) in the liver is almost the same as in muscle $(P=0.9991)$, and is $73 \%$ of the concentration in the kidney, being this difference significant $(P=0.0345)$. Mean concentration in muscle is $72 \%$ of the concentration in the kidney but this difference is not significant $(P=0.2909)$. So, for Fe, the concentration in organs follows the order liver $<$ kidney, whereas muscle has no significant differences with any of those two organs.

\section{Toxic Metals}

As with essential metals, the application of the linear mixed model did not detect any significant effects associated to age $(P=0.6375)$, type of diet $(P=0.0744)$, or sex $(P=0.8523)$, but there were significant differences in the concentrations between metals $(P=0.0074)$ and organs $(P<0.0001)$, as well as in its interaction $(P=0.0004)$. The adjusted mean concentrations were $0.055 \mathrm{mg} / \mathrm{kg}(C I$ $95 \%[0.037,0.081])$ for As, $0.064 \mathrm{mg} / \mathrm{kg}$ (CI 95\% [0.043, 0.093 ] for $\mathrm{Cd}, 0.040 \mathrm{mg} / \mathrm{kg}$ (CI 95\% [0.026, 0.060] for $\mathrm{Pb}$, and $0.027 \mathrm{mg} / \mathrm{kg}$ (CI 95\% [0.017, 0.042] for $\mathrm{Hg}$. When global concentrations of toxic metals are compared (Table 3), the concentration of $\mathrm{Hg}$ is significantly less 
than As $(P=0.036)$ and $\mathrm{Cd}(P=0.0066)$, but has no significant difference with $\mathrm{Pb}(P=0.4771)$; $\mathrm{As}, \mathrm{Cd}$, and $\mathrm{Pb}$ have no significant differences in their respective global concentrations.

Toxic metals also showed significant differences in their concentrations, in the various organ $(P=0.0004)$. Table 5 shows the adjusted means and a $95 \%$ confidence interval for the concentration of toxic metals in the different organs. Figure 2 represents these means and confidence intervals.

$\mathrm{Hg}$ and $\mathrm{Pb}$ show their highest concentrations in the liver, whereas As and $\mathrm{Cd}$ reach their largest values in the kidney. Ratios of adjusted concentrations for toxic metals between the organs and $95 \%$ confidence intervals, as well as $P$-values for testing the significance of the ratios, are shown in Table 6. It can be seen that adjusted mean concentration of $\mathrm{Hg}$ in the liver is 4.23 times greater than in muscle $(P<0.0001)$ and 1.82 times greater than in the kidney $(P=0.0078)$. In muscle, the mean concentration of $\mathrm{Hg}$ is $43 \%$ of the concentration in the kidney $(P=0.0001)$. So, for $\mathrm{Hg}$, the concentrations follow the order liver $>$ kidney $>$ muscle.

We also see that mean concentration of As in the liver is 6.5 times greater than in muscle $(P<0.0001)$, but shows no significant difference with the kidney $(P=0.9316)$. Also, mean concentration in muscle is only $13 \%$ of the mean concentration in the kidney $(P<0.0001)$. So, the concentrations of As in the organs follow the order liver $=$ kidney $>$ muscle.

The adjusted mean concentration of $\mathrm{Cd}$ in the liver is 4.05 times greater than in muscle $(P=0.0036)$ but shows no significant difference with the kidney $(P=0.7541)$. Also, mean concentration in muscle is only $18 \%$ of the mean concentration in the kidney $(P<0.0001)$.

So, the concentrations of $\mathrm{Cd}$ in the organs are liver $=$ kidney $>$ muscle. Lastly, $\mathrm{Pb}$ does not show significant differences between any of the organs.

\section{Discussion}

\section{Essentials Metals}

The results of the present study for $\mathrm{Cu}$ content are in accordance with those obtained by Chafik et al. (2004) in Morocco, where the liver appeared as the organ with highest presence of this metal [35]. Cu is stored by the liver and excreted into the bile, but some inherited defects in copper metabolism result in chronic accumulation that eventually causes hepatitis, hepatic failure, cirrhosis, and ultimately death [36].
Fig. 2 Adjusted mean and 95\% confidence interval for concentration of toxic metals by organ

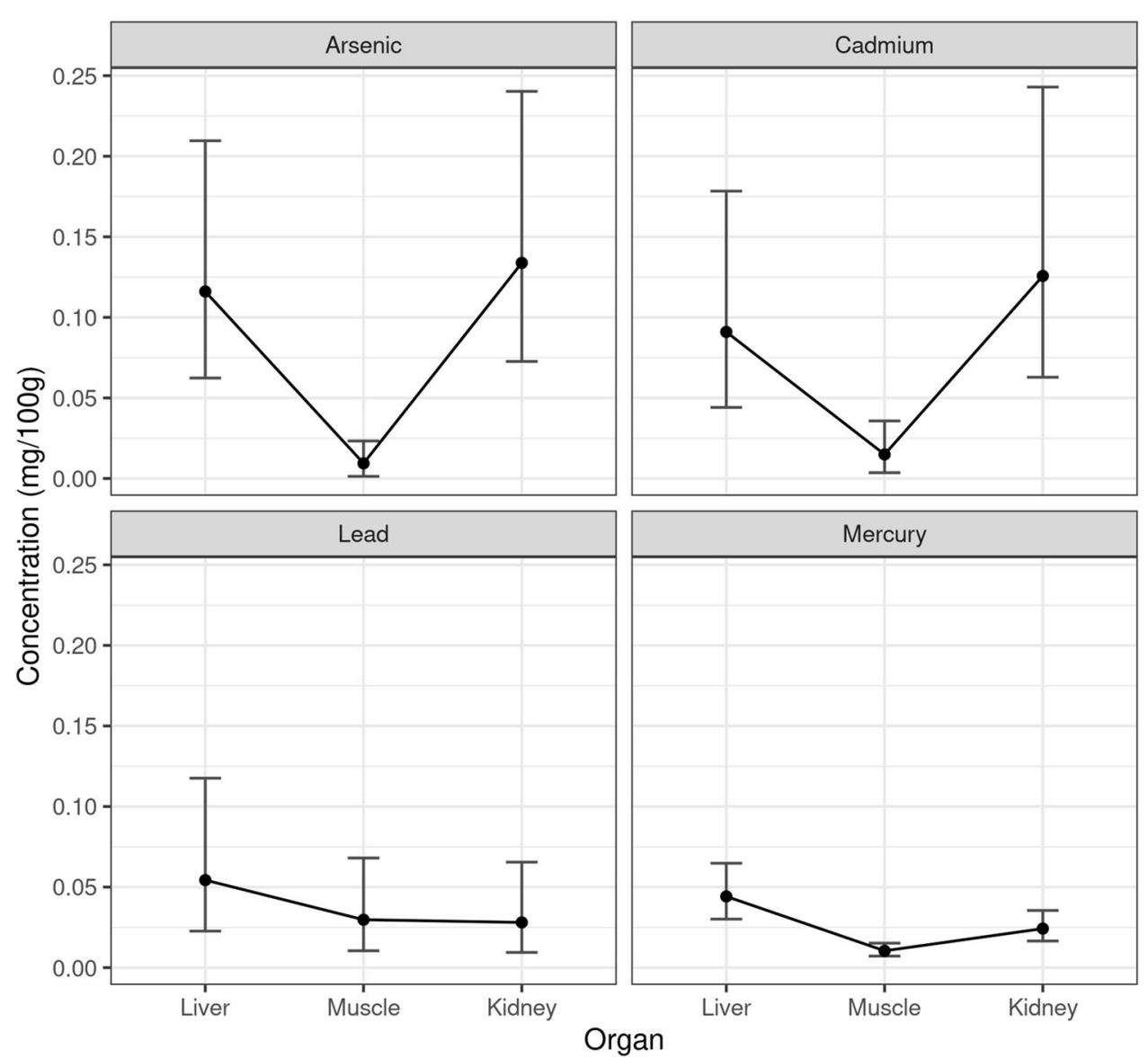


Since it has been demonstrated that the level of $\mathrm{Cu}$ in organs like the liver is depending on the content in diet [37], more information about feeding locations will be useful to obtain comparable information. $\mathrm{Cu}$ level in the edible tissues of the dromedary from our study (Table 3 ) was also similar to the level reported by other authors $[4,10,11,14]$.

Regarding the ages of the camels, Sahraoui et al. reported that $\mathrm{Cu}$ content in dromedary meat from Algeria was almost the same for different age ranges $(0.31 \pm 0.1 \mathrm{mg} / 100 \mathrm{~g}$ for $<3$ years old and $0.32 \pm 0.08 \mathrm{mg} / 100 \mathrm{~g}$ for $4-6$ years old individuals) [14], while our results showed an increase of $\mathrm{Cu}$ concentrations for 4-5 year-old animals regarding those $0-3$ years old and olds ones. Although $\mathrm{Cu}$ content in edible tissues of camel from Saudi Arabia was also comparable with ours (ranging from 0.006 to $0.502 \mathrm{mg} / 100 \mathrm{~g}$ ), concentration in the liver was lower $(0.166 \pm 0.092 \mathrm{mg} / 100 \mathrm{~g})$ than ours [4]. Moreover, two studies, performed in Sudan, reported $\mathrm{Cu}$ concentration in meat lower than ours $(0.002 \pm 0.0050 \mathrm{mg} / 100 \mathrm{~g} \mathrm{[6]}$ and $0.16 \mathrm{mg} / 100 \mathrm{~g}$ [34]).

The range of $\mathrm{Zn}$ concentrations measured in this study was comparable to those found in the literature for different edible parts of camel $[11,13,16]$. $\mathrm{Zn}$ concentration found in camel meat from Algeria was $3.3 \mathrm{mg} / 100 \mathrm{~g}$ [14], while Hammad et al. (2019) reported that camel meat from Sudan contained $3.49 \pm 0.002 \mathrm{mg} / 100 \mathrm{~g}$ of $\mathrm{Zn}$ [34]. However, other authors found a very low concentration in meat of camel from Sudan (0.066 mg Zn/100 g) [6]. Zn content in edible tissues of camel from Saudi Arabia was also much lower than the one found in our study, in the ranges $0.133-0.355 \mathrm{mg} / 100 \mathrm{~g}$ in the kidney, $0.307-0.677 \mathrm{mg} / 100 \mathrm{~g}$ in the liver, and $0.022-0.199 \mathrm{mg} / 100 \mathrm{~g}$ in muscle [4]. In other study carried out in Morocco, muscle and the liver were the organs that accumulated the highest concentration of $\mathrm{Zn}$ [35]. The higher presence of $\mathrm{Zn}$ in the muscle than in other studied samples is related with its importance for skeletal muscle performance and resistance to fatigue [38], and it performs important roles in regulating whole-body metabolism [39].

This study showed Fe levels similar with findings in other animals from the same region, such as Algeria [11, 14] or more distant areas like Saudi Arabia [10], Iran [16], Iraq [23], or Sudan [6]. In detail, Sahraoui et al. (2018) from Algeria samples reported that Fe concentration is $6.10 \pm 0.45 \mathrm{mg} / 100 \mathrm{~g}$ in camel meat [14], while camel sausages from Sudan contained $3.78 \pm 0.04 \mathrm{mg} / 100 \mathrm{~g}$ of $\mathrm{Fe}$ [6]; both of them are in the same range of our results. However, higher values were found in camel muscle from that country $(45.5 \mathrm{mg} / 100 \mathrm{~g})$ [25]. Regarding other body parts, El-Ghareeb et al. (2019) reported the following concentrations in camel from Saudi Arabia: $1.82 \pm 0.22 \mathrm{mg} / 100 \mathrm{~g}$ in the liver and $1.32 \pm 0.25 \mathrm{mg} / 100 \mathrm{~g}$ in the kidney, which were lower than the outcomes of this work (up to 6 and 12 times for the liver and kidney, respectively) [4]. Some authors suggest that the different metabolism mechanisms occurred in the kidney are modulated directly or indirectly, among other factors, by cellular iron content, and they pointed out the treatment of iron-induced kidney injury by customized iron removal or relocation [40].

Given that some authors stated that the presence of some trace metals is clearly linked to diet composition, their levels can be related with both pasture and drinking water [38]. Most animals of this study come from Inchiri (Mauritania) which is an area known by the presence of metal exploitations, especially $\mathrm{Cu}, \mathrm{Fe}$, and gold. So, the level of these metal in dromedary meat could be related with this activity.

\section{Toxic Metals}

Toxic metals are non-essential elements, and they can be accumulated in body causing diseases, especially nerve's system problems. The results show that metals are more concentrated in the liver than in other studied parts of the camels which is linked with its biological role; the liver becomes the organ most affected by trace metal accumulation. So, these results are like the provided by other studies.

$\mathrm{Hg}$ content in edible camel parts was comparable with those measured in Saudi Arabia by Alturiqui et al. (0.024- $0.054 \mathrm{mg} /$ $\mathrm{kg}[10])$, but higher than those found in camel from Algeria $(0.006 \pm 0.002 \mathrm{mg} / \mathrm{kg}$ [23] $)$ and Iraq $(0.0011-0.0045 \mathrm{mg} / \mathrm{kg}$ [39]).

$\mathrm{Pb}$ concentration in camel meat from Mauritania was lower than the value measured in Algeria $(0.64 \pm 0.04 \mathrm{mg} / \mathrm{kg}$ [23]), Saudi Arabia [10], and Iraq [23]. The high concentration of $\mathrm{Pb}$ in the liver also agrees with the results obtained by Abdelbasset et al., which confirm the previously mentioned trend of this organ to accumulate some metals like $\mathrm{Pb}$ [41].

As and $\mathrm{Cd}$ concentrations in the kidney and liver did not show significant variation probably because of kidney biological role, since these metals are cleaned from blood by the kidney in order to be excreted in urine.

The level of As in camel meat of this study is similar to these obtained by Meligy et al. in Saudi Arabia camel meat [24], but lower than these reported by Asli et al. from Iran [16].

Concentrations of $\mathrm{Cd}$ are lower than the results reported by authors from Algeria $(0.116 \pm 0.07 \mathrm{mg} / \mathrm{kg})$, Saudi Arabia, and Iran [16, 24, 42].

The authors, except El-Ghareeb et al. from Saudi Arabia [4], found that these toxic metals $(\mathrm{Cd}, \mathrm{Pb}$, and $\mathrm{As})$ were more concentrated in the liver than in the kidney and muscle $[16,23,34,39]$.

\section{Conclusions and Future Trends}

The dromedary meat is widely consumed in Mauritania, so the control of their quality regarding the presence of pollutants is essential for the development and maintenance of 
the breeding activity and citizen health care. The results of this study allowed to determine essential and toxic metal concentrations in samples of the dromedaries.

No significant differences associated with age, sex, or type of diet were detected in the found concentrations for the studied essentials metals. However, they were significant between metals and organs, as well as in the interaction between both variables. The highest concentrations were found for Fe, followed by $\mathrm{Zn}$, while the lowest levels were measured for $\mathrm{Cu}$. Moreover, it was noticed that $\mathrm{Cu}$ was the most concentrated metal in the liver, $\mathrm{Fe}$ in the kidney, and $\mathrm{Zn}$ in muscle. Regarding the target toxic metals, found differences in the measured concentrations were not significant with respect to age, type of diet, or sex, but they were significant between metals and organs, as well as in its interaction. For this group of metals, the highest concentrations of $\mathrm{Hg}$ and $\mathrm{Pb}$ were found in the liver, while As and $\mathrm{Cd}$ were highest in the kidney.

Given that the concentrations of several metals in the different organs seem to be dependent on the content in diet, future works must be focused to offer information about meat origin. It would be interesting to know if location is a variable with statistical significance in the occurrence of metal traces, and from this starting point, design a study to investigate the differences between the quality of food among several locations.

Although in general, the obtained results are comparable with those reported by works carried out in Africa, it is necessary to carefully observe the levels of metals in edible parts of camels and dromedaries, especially toxic ones, since they could be dangerous when the consume of this meat by population is frequent.

The findings of this study can be used as reference of trace metal survey in meat, and the new information could be added to the available ones about the concentration data in other food, such as fish and chicken, to assess Mauritania citizen daily intake of trace metal.

Funding Open Access funding provided thanks to the CRUE-CSIC agreement with Springer Nature.

Data Availability The authors confirm that all relevant data are included in the article.

\section{Declarations}

Conflict of Interest The authors declare no competing interests.

Open Access This article is licensed under a Creative Commons Attribution 4.0 International License, which permits use, sharing, adaptation, distribution and reproduction in any medium or format, as long as you give appropriate credit to the original author(s) and the source, provide a link to the Creative Commons licence, and indicate if changes were made. The images or other third party material in this article are included in the article's Creative Commons licence, unless indicated otherwise in a credit line to the material. If material is not included in the article's Creative Commons licence and your intended use is not permitted by statutory regulation or exceeds the permitted use, you will need to obtain permission directly from the copyright holder. To view a copy of this licence, visit http://creativecommons.org/licenses/by/4.0/.

\section{References}

1. Faye B, Abdelhadi O, Raiymbek G, Kadim I, Hocquette JF (2013) La production de viande de chameau : état des connaissances. Situation actuelle et perspectives. Prod Anim 26:247-258

2. Bekhit A, Farouk M (2013) Nutritive and health value of camel meat. Camel Meat and Meat Products. CAB International. Oxfordshire UK, p 205-223. https://doi.org/10.1079/97817 80641010.0205

3. Siham A, Elshafia S, Huda M (2015) Pyrex Journals 2035-4344. Reading 10:100

4. El-Ghareeb WR, Darwish WS, Meligy AMA (2019) Metal contents in the edible tissues of camel and sheep: human dietary intake and risk assessment in Saudi Arabia. Jpn J Vet Res 67:514. https://doi.org/10.14943/jjvr.67.1.5

5. Picot A (2003) Intoxication de l'organisme par les métaux lourds et autres toxiques. Le mercure, le plomb et le cadmiu, trois métaux traces toxiques. Conférence ADNO. 2003 Paris. 29 nov 2003

6. Saidahmed AW, Ahmed EZD, Alamin AS (2018) Assessment of concentration of some heavy metals in sausage of beef, goat and camel meat and conformity with international standards. Sudan J Sci Technol 19(2):63-71

7. EFSA (2009) Scientific opinion on cd in food. Efsa J 980:1-139

8. EFSA (2010) Scientific opinion on lead in food. Efsa J 8(4):1-147

9. Boumehres A (2010) Etude comparative des techniques d'extraction des éléments traces métalliques dans le foie, le rein et le lait et leur détermination par spectrophotométrie d'absorption atomique (flamme et four graphite). Université de Mentouri de Coustane. http://archives.umc.edu.dz/handle/123456789/8424. Accessed Sept 2021

10. Alturiqi AS, Albedair LA (2012) Evaluation of some heavy metals in certain fish, meat and meat products in Saudi Arabian markets. Egypt J Aquat Res 38:45-49. https://doi.org/10.1016/j.ejar.2012. 08.003

11. Badis B (2014) Levels of selected heavy metals in fresh meat from cattle, sheep, chicken and camel produced in Algeria. Annu Res Rev Biol 4:1260-1267. https://doi.org/10.9734/arrb/2014/7430

12. Bala A, Junaidu AU, Salihu MD, Agaie BM, Saulawa MA, Musawa AI, Ahmad KH (2018) Determination of heavy metal residues in slaughtered camels at Sokoto and Gusau modern abattoirs, Nigeria. J Heal Pollut 8(20):181204. https://doi.org/10.5696/ 2156-9614-8.20.181204

13. Chafik A, Essamadi A, Eddoha R, Bagri A, Nasser B, Faye B, Bengoumi M (2015) Trace elements and heavy metals in organs of camels (Camelus Dromedarius) slaughtered in Casablanca City, Morocco, in: Konuspayeva, G. (Ed.), 4th Conference of ISOCARD "Silk road camel: the camelids, main stakes for sustainable development." Almaty, Kazakhstan

14. Sahraoui N, Moula N, Boudjenah S, Hornick J-L (2018) Main mineral contents in camel meat in Algeria. Rev Elev Med Vet Pays Trop 71(4):163-166. https://doi.org/10.19182/remvt.31672

15. Al-Perkhdri A (2021) Study of the some heavy metals residues in the camel meat in different regions of Kirkuk governorate during 
the spring and summer seasons. In: IOP Conference series: Earth and environmental science, vol 735, no.1.IOP Publishing, $p$ 012080

16. Asli M, Azizzadeh M, Moghaddamjafari A, Mohsenzadeh M (2020) Copper, iron, manganese, zinc, cobalt, arsenic, cadmium, chrome, and lead concentrations in liver and muscle in Iranian camel (Camelus dromedarius). Biol Trace Elem Res 194:390-400. https://doi.org/10.1007/s12011-019-01788-2

17. Morshdy AEMA, El Bayomi RM, Abd El Galil GM, Mahmoud AFA (2018) Heavy metal concentrations and their risk assessment in marketed slaughtered animals in Sharkia Governorate, Egypt. Slov Vet Res 55:103-112. https://doi.org/10.26873/ SVR-635-2018

18. Ali A, Derar DR, Abdel-Elmoniem EM, Almundarij TI (2019) Impotentia generandi in male dromedary camels: heavy metal and trace element profiles and their relations to clinical findings and semen quality. Trop Anim Health Prod 51:1167-1172. https://doi. org/10.1007/s11250-019-01803-7

19. Ali A, Derar DR, Abdel-Elmoniem EM, Almundarij TI (2020) Cadmium in seminal plasma of fertile and infertile male dromedary camels. Biol Trace Elem Res 193:162-165. https://doi.org/ 10.1007/s12011-019-01688-5

20. Athamna OM, Bengoumi M, Faye B (2012) Selenium and copper status of camels in Al-Jouf area (Saudi Arabia). Trop Anim Health Prod 44:551-556. https://doi.org/10.1007/s11250-011-9910-5

21. Mohamed HE (2004) The zinc and copper content of the plasma of sudanese camels (Camelus dromedarius). Vet Res Commun 28:359-363. https://doi.org/10.1023/B:VERC.0000035015. 96444.32

22. Parsaei P, Rahimi E, Shakerian A (2019) Concentrations of cadmium, lead and mercury in raw bovine, ovine, caprine, buffalo and camel milk. Polish J Environ Stud 28:4311-4318. https://doi.org/ 10.15244/pjoes/94809

23. Mohammed SG, Abdulsahib HT, Jasim IM, Jabbar MT (2011) Assessment of camel meat pollution with trace metals in desert area of Basra province. Am J Agric Biol Sci 6:475-479. https:// doi.org/10.3844/ajabssp.2011.475.479

24. Meligy AMA, Al-Taher AY, Ismail M, Al-Naeem AA, El-Bahr SM, El-Ghareeb WR (2019) Pesticides and toxic metals residues in muscle and liver tissues of sheep, cattle and dromedary camel in Saudi Arabia. Slov Vet Res 56:157-166. https://doi.org/10. 26873/SVR-753-2019

25. SNIM résultats oppérationnels et financier 2020 disponible sur le site: https://www.snim.com/index.php/news-a-media/news/3532021-04-28-12-04-58.html

26. El Mahmoud MSH, Montesdeoca-Esponda S, Santana-Del Pino A, Zamel ML, Brahim M, Tfeil H, Santana-Rodriguez JJ, Sidoumou Z, Sidi'Ahmed-Kankou M (2019) Distribution and health risk assessment of cadmium. Lead. and mercury in freshwater fish from the right bank of Senegal River in Mauritania. Environ Monit Assess J 191:493. https://doi.org/10.1007/s10661-019-7627-5

27. Taweel A, Shuhaimi-Othman M, Ahmad AK (2013) Assessment of heavy metals in tilapia fish (Oreochromis niloticus) from the Langat River and Engineering Lake in Bangi. Malaysia. and evaluation of the health risk from tilapia consumption. Ecotoxicol Environ Saf 93:45-51. https://doi.org/10.1016/j.ecoenv.2013.03. 031
28. Mendil D, Ömer FÜ, Mustafa T, Mustafa S (2010) Determination of trace metals in different fish species and sediments from the River Yesilirmak in Tokat, Turkey. Food Chem Toxicol 48:1383-1392

29. Dig-Acids (2001) Guide lines for microwave acid digestion. In: ED (ed) Dig Acid. http://www.scribd.com/doc/6789831/DigAc ids. Accessed July 2021

30. CEAEQ, Centre D'expertise En Analyse Environnementale Du Québec. Détermination du mercure dans les tissus biologiques et les sédiments par décomposition thermique : dosage par photométrie UV, MA. 207 - Hg 2.1, Ministère du Développement durable, de l'Environnement, de la Faune et des Parcs du Québec, 2013, 11. https://www.ceaeq.gouv.qc.ca/methodes/pdf/MA207Hg21. pdf. Accessed May 2021

31. R Core Team (2021) R: a language and environment for statistical computing. R Foundation for Statistical Computing, Vienna, Austria. https://www.R-project.org/. Accessed May 2021

32. Pinheiro J, Bates D, DebRoy S, Sarkar D, R Core Team (2021) _nlme: linear and nonlinear mixed effects models_. R package version 3.1-152, <https://CRAN.R-project.org/package=nlme $>$

33. Lenth R.V (2021) Emmeans: estimated marginal means, aka leastsquares means. R package version 1.6.1. https://CRAN.R-project. org/package $=$ emmeans

34. Hammad HHM, Jin G, Ma M, Khalifa I, Shukat R, Elkhedir AE, Zeng Q, Noman AE (2019) Comparative characterization of proximate nutritional compositions, microbial quality and safety of camel meat in relation to mutton, beef, and chicken. LWT Food Sci Technol. https://doi.org/10.1016/j.lwt.2019.108714

35. Chafik A, Essamadi A, Eddoha R, Bagri A, Nasser B, Faye B (2014) Trace elements and heavy metals in organs of camels (Camelus dromedarius) slaughtered in Casablanca city. Morocco J Camel Pract Res 21(2):145-152

36. Pourahmad J, O'Brien PJ (2000) A comparison of hepatocyte cytotoxic mechanisms for $\mathrm{Cu} 2+$ and $\mathrm{Cd} 2+$. Toxicology 143(3):263-273

37. Faye B, Grillet C (1984) La carence en cuivre chez les ruminants domestiques de la région d'Awash (Ethiopie). Rev Elev Med Vét Pays Trop 37:42-60

38. Isaacson A, Sandow A (1963) Effects of zinc on responses of skeletal muscle. J Gen Physiol 46(4):655-677

39. Lukaski HC (2000) Magnesium, zinc, and chromium nutriture and physical activity. Am J Clin Nutr 72(2):585S-593S

40. Martines AMF, Masereeuw R, Tjalsma H, Hoenderop JG, Wetzels JFM, Swinkels DW (2013) Iron metabolism in the pathogenesis of iron-induced kidney injury. Nat Rev Nephrol 9(7):385-398

41. Abdelbasset C, Rabia E, Abdallah B, Boubker N, AbdelKhalid E (2014) Distribution of trace elements and heavy metals in liver, lung, meat, heart and kidney of cattle, sheep, camel and equine slaughtered in Casablanca city-Morocco. IJSER 5:294-303

42. Badis B, Rachid Z, Esma B (2014) Levels of selected heavy metals in fresh meat from cattle, sheep, chicken and camel produced in Algeria. Annu Res Rev Biol 4(8):1260-1267

Publisher's Note Springer Nature remains neutral with regard to jurisdictional claims in published maps and institutional affiliations. 